\title{
IPTEKS ANGGARAN KAS UNTUK IBU - IBU PKK DI DESA KAUDITAN I KECAMATAN KAUDITAN KABUPATEN MINAHASA UTARA
}

\author{
Herman Karamoy ${ }^{1}$, Heince Rudy Nicky Wokas ${ }^{2}$ \\ ${ }^{1}$ Jurusan Akuntansi, Fakultas Ekonomi dan Bisnis, Universitas Sam Ratulangi, Jl. Kampus Bahu, Manado, \\ 95115, Indonesia \\ E-mail : herman.karamoy@unsrat.ac.id
}

\begin{abstract}
Performance-based budgeting is very important for firm management in case to estimte the ending financial statement. Also performance-based budgeting is very important to control the inflows and outflows of cash. Kauditan village is one of developed region in North Sulawesi but most of household in that area still have less understanding about budgeting especially cash budget. The applied science about cash budgeting is effective for those household in Kauditan village.
\end{abstract}

Keywords : cash, budgeting, inflows, outflows

\section{PENDAHULUAN}

Penganggaran berbasis kinerja merupakan metode penganggaran bagi manajemen untuk mengaitkan setiap pendanaan yang dituangkan dalam kegiatan-kegiatan dengan keluaran dan hasil yang diharapkan, termasuk efisiensi dalam pencapaian hasil dari keluaran tersebut. Keluaran dan hasil tersebut dituangkan dalam target kinerja pada setiap unit kerja. Sedangkan bagaimana tujuan itu dicapai, dituangkan dalam program, diikuti dengan pembiayaan pada setiap tingkat pencapaian tujuan. Anggaran berbasis rumah tangga didefinisikan sebagai instrumen kebijakan yang berisi satu atau lebih kegiatan yang akan dilaksanakan oleh rumah tangga untuk mencapai sasaran dan tujuan, serta memperoleh alokasi anggaran atau kegiatan masyarakat yang dikoordinasikan. Aktivitas tersebut disusun sebagai cara untuk mencapai tujuan tahunan.

Desa Kauditan I Kecamatan Kauditan sebagai bagian dari daerah otonomi menarik untuk diamati secara khusus mengingat secara birokrasi pemerintahan dan pelayanan publik termasuk daerah yang dianggap memiliki kemampuan dalam menerapkan "good governance". Pemerintah daerah telah menerapkan berbagai praktek pemerintahan seperti antara lain: kebijakan dan pelayanan publik menyangkut administrasi, perijinan usaha/ lainnya, kesehatan, pendidikan, dan proses lelang proyek pembangunan fisik. Namun demikian walaupun kemajuan dalam bidang pelayanan publik semakin baik, tetapi sebagaimana daerah lainnya, Kabupaten Minahasa Utara juga memiliki sebagian masyarakat yang perlu ditingkatkan akan pemahaman atas pajak yang diselenggarakan oleh daerah maupun negara, mengingat secara umum, distribusi pendapatan masyarakat Kabupaten Minahasa Utara masih perlu dikembangkan ke arah yang lebih merata yang idealnya tentu diharapkan dari upaya peningkatan kesejahteraan kelompok masyarakat marginal. Dengan adanya latar belakang diatas maka permasalahan dari mitra adalah bagaimana menyususun anggaran kas bagi ibu - ibu PKK di Desa Kauditan I Kecamatan Kauditan Kabupaten Minahasa

\section{TINJAUAN PUSTAKA}

Kieso et al. (2013) menjelaskan bahwa kas merujuk pada mata uang dan kebutuhan yang dapat dengan segera dibayarkan, sedangkan setara kas adalah investasi atau aset yang dapat segera ditunaikan dalam jangka waktu yang pendek atau sekurang-kurangnya tidak 
lebih dari 3 bulan. Lasupu dan Wangkar (2018), Taogan et al. (2018), dan Tiow dan Tirayoh (2018) menemukan bahwa sebuah sistem informasi akuntansi untuk kas diperlukan dalam rangka pengendalian kas. Laotongan et al. (2015), Atika dan Pusung (2018), Tambunan dan Runtu (2018), dan Usman dan Rondonuwu (2018) menunjukkan bahwa sistem kas kecil merupakan salah satu implementasi sistem informasi akuntansi guna membantu pengendalian atas pengeluaran kas. Berdasarkan konsep ini, maka Kakasih et al. (2018) menunjukkan bahwa laporan arus kas merupakan tahap akhir untuk pertanggungjawaban dan dasar untuk penilaian kinerja keuangan.

Horngren et al. (2012) menjelaskan bahwa salah satu anggaran yang sangat dibutuhkan oleh perusahaan adalah anggaran keuangan. Menurut Horngren et al. (2012), sebuah anggaran induk harus mengikutsertakan anggaran laba rugi, anggaran untuk pengeluaran modal, anggaran untuk penerimaan kas, dan pembayaran utang. Menurut Horngren et al. (2012), seluruh rangkaian komponen anggaran ini disebut sebagai anggaran kas, dimana anggaran kas bertujuan agar perusahaan dapat mengestimasi nilai akhir kas sejak dianggarkannya saldo awal kas hingga pelaporannya dalam laporan keuangan perusahaan. Menurut Warren et al. (2009), dan Libby et al. (2011) bahwa anggaran kas mengestimasi arus kas masuk dan arus kas keluar dalam sebuah periode tertentu, dimana anggaran ini mengintegrasi seluruh anggaran operasional, pengeluaran modal, pembayaran dividen, dan pembayaran utang yang dibutuhkan oleh perusahaan.

\section{METODE DAN TEKNIK PENERAPAN IPTEKS}

\subsection{Metode Penerapan Ipteks}

Penerapan ipteks ditempuh dengan cara pelatihan dengan pendekatan metode studi kasus yang langsung diaplikasikan pada software untuk teknis penyusunan anggaran.

\subsection{Teknik Penerapan Ipteks}

Teknik yang digunakan untuk penerapan ipteks adalah sebagai berikut :

- Melakukan penyuluhan, diskusi dan bagi pendapat mengenai masalah dan upaya dalam penyusunan anggaran kas bagi ibu - ibu PKK.

- Memberikan pemahaman tentang pentingnya tata administrasi keuangan dalam untuk kemudahan alokasi keuangan.

- Memberikan pengetahuan dasar perhitungan anggaran kas dengan menggunakan software komputer sederhana yang lebih aplikatif.

- Memberikan pengetahuan dasar manajerial bagi ibu - ibu PKK..

\section{PEMBAHASAN}

\subsection{Gambaran Objek Penerapan Ipteks}

Desa Kauditan I Kecamatan Kauditan Kabupaten Minahasa Utara merupakan salah satu kelurahan yang berlokasi di wilayah Kabupaten Minahasa Utara. Struktur masyarakat yang kompleks turut mencerminkan struktur perekonomian yang tercipta di wilayah tersebut, baik dari segi usaha kecil, usaha menengah maupun usaha pertanian. Adanya alih pengetahuan atas penganggaran bagi kelompok masyarakat yang tergabung dalam kelompok PKK diharapkan akan membuat masyarakat akan lebih menyadari pentingnya aspek penganggaran bagi keluarga dalam meningkatkan taraf hidup keluarga.

\subsection{Pembahasan}

Kelompok Ibu-Ibu PKK Desa Kauditan 1 selama ini telah memainkan peran yang sangat strategis dalam upaya pembangunan dan peningkatan kualitas kehidupan keluarga, keberadaan PKK telah mendapat pengakuan dari pemerintah, masyarakat bahkan lembaga internasional atas peranan dan kiprahnya dalam ikut membantu masyarakat mengatasi berbagai masalah diberbagai bidang kehidupan terutama kesehatan, pendidikan, dan ekonomi keluarga. Desa Kauditan I Penduduknya Asli Minahasa Etnis Tonsea, Penduduk 
tambahan yang dari Gorontalo, Sanger Talaud, Jawa dan Etnis lain yang sudah kawin-mawin dengan masyarakat adat Desa Kauditan I . Lainnya hanya pencari kerja/penggarap/tamu. Hubungan antar masyarakat terjalin dengan baik berdampingan rukun dan damai. KAMTIBMAS Desa Kauditan I aman terkendali melalui : Pertahanan Sipil/Linmas, Forum Mapalus Kamtibmas, Sosial budaya, Adat dan Agama/Peribadatan berjalan sangat baik/rukun melalui tuntunan/peraturan-peraturan Badan Permusyawarah Desa (BPD) dan Forum Komunikasi Umat Beragama (FKUB).

Masyarakat Desa Kauditan I Mayoritas adalah Petani. Hasil pertanian yang menjadi pokok unggulan andalan adalah : Kelapa, Padi sawah dan Jagung. Selain itu dalam upaya pengelolaan areal di sektor Pertanian, Perkebunan, juga dikembangkan pengelolaan di sektor Perikanan air tawar dan Peternakan. Keberadaan Ibu - Ibu PKK yang mampu mengelola keuangan rumah tangga dengan baik akan membantu dan meringankan ekonomi keluarga, sehingga PKK dapat menjadi yang terdepan dalam mengatasi kesulitan keluarga dan menjadi pembawa kesejahteraan untuk keluarga dan masyarakat. Bimbingan teknis administrasi penganggaran kepada seluruh jajaran TP-PKK untuk meningkatkan pendidikan dan ketrampilan yang diperlukan, dalam upaya mencerdaskan kehidupan bangsa, peningkatan pendapatan, peningkatan kualitas dan kuantitas pangan keluarga, meningkatkan derajat kesehatan, kelestarian lingkungan hidup, hingga meningkatkan pengelolaan gerakan PKK baik kegiatan pengorganisasian baik kegiatan pengorganisasian maupun pelaksanaan program-programnya yang mengarah pada pemberdayaan keluarga yang disesuaikan dengan situasi dan kondisi masyarakat setempat.

Anggaran (Budget) adalah rencana kuantitatif aktivitas usaha sebuah organisasi (pemasaran, produksi dan keuangan) ; anggaran mengidentifikasi sumber daya dan komitmen yang dibutuhkan untuk memenuhi tujuan organisasi selama periode dianggarkan. Penganggaran adalah penciptaan suatu rencana kegiatan yang dinyatakan dalam ukuran keuangan. Penganggaran memainkan peran penting di dalam perencanaan, pengendalian, dan pembuatan keputusan. Anggaran juga untuk meningkatkan koordinasi dan komunikasi. Bagi masyarakat Desa Kauditan 1 terutama ibu - ibu PKK sangat berguna membuat perencanaan keuangan rumah tangga dengan penyusunan anggaran, karena kebanyakan mata pencarian masyarakat desa kauditan 1 adalah petani kelapa, sawah dan jagung yang termasuk tanaman musiman, karena itu aliran kas masuk dan kas keluar harus diatur sedemikian rupa agar bisa memenuhi kebutuhan rumah tangga. Contoh penerapan penyusunan anggaran kas :

Tabel 1. Contoh penyusunan anggaran kas sederhana

\begin{tabular}{lrrrrr}
\hline \multirow{2}{*}{ Keterangan } & \multicolumn{5}{c}{ Kwartal } \\
\cline { 2 - 6 } & \multicolumn{1}{c}{ I } & \multicolumn{1}{c}{ II } & \multicolumn{1}{c}{ III } & \multicolumn{1}{c}{ Tahun } \\
\hline Expektasi Penjualan Hasil Pertanian & 20.000 & 60.000 & 30.000 & 18.000 & 128.000 \\
Expektasi Uang berjaga-jaga & 12.000 & 6.000 & 3.600 & 4.000 & 4.000 \\
Jml Kebutuhan (konsumsi) & $\mathbf{3 2 . 0 0 0}$ & $\mathbf{6 6 . 0 0 0}$ & $\mathbf{3 3 . 6 0 0}$ & $\mathbf{2 2 . 0 0 0}$ & $\mathbf{1 3 2 . 0 0 0}$ \\
Tabungan (jika ada) & -3000 & -12000 & -6000 & -3600 & -3000 \\
Jml yg akan dibutuhkan & $\mathbf{2 9 . 0 0 0}$ & $\mathbf{5 4 . 0 0 0}$ & $\mathbf{2 7 . 6 0 0}$ & $\mathbf{1 8 . 4 0 0}$ & $\mathbf{1 2 9 . 0 0 0}$ \\
\hline
\end{tabular}

Berdasarkan Tabel 1 diatas maka kebutuhan selama 1 tahun dapat diprediksi sehingga kekuranga kas dapat diantisipasi dengan menabung pada panen sebelumnya atau apabila ada kelebihan pada panen berikutnya,sehingga ibu - ibu PKK mampu dengan bijaksana mengatur keuangan rumah tangga mereka masing-masing. Hasil penerapan anggaran kas ini diharapkan akan memenuhi Ketepatan solusi dalam penanganan permasalahan ibu-ibu PKK karena dengan anggaran :

- Bisa memprediksi transaksi dan kejadian finansial serta non finansial dikeluarga pada masa yang akan datang. 
- Mengembangkan informasi yang akurat dan bermakna bagi penerima anggaran dalam hal ini ibu-ibu PKK.

Keterbatasan solusi dalam penanganan masalah adalah sebagai berikut :

- Dalam banyak kejadian, anggaran cenderung terlalu menyederhanakan fakta situasi nyata di lapangan.

- Proses penganggaran bukanlah ilmu murni dan pertimbangan yang baik memainkan peran esensial.

- Adanya pemahaman yang masih tradisional dalam menerapkan konsep anggaran kas serta analisisnya.

- Keterbatasan dalam wawasan yang didukung oleh latar belakang tingkat pendidikan khususnya bidang ekonomi dan manajemen modern.

Sukses suatu sistem penganggaran tergantung pada bagaimana factor-faktor manusia dipertimbangkan secara serius. Untuk mengurangi perilaku disfungsional, suatu Rumah Tangga perlu menghindari anggaran yang terlalu menekankan pada mekanisme kendali. Skala prioritas kebutuhan yang lainnya harus dievaluasi sebagai tambahan terhadap anggaran. Anggaran dapat disempurnakan sebagai ukuran-ukuran kebutuhan dengan menggunakan penganggaran partisipatif dan perangsang nonmoneter lainnya, menyediakan umpan balik yang sering, menggunakan penganggaran fleksibel, menjamin bahwa tujuan yang dianggarkan mencerminkan kenyataan, dan para pengelola anggaran hanya bertanggung jawab untuk biaya-biaya yang terkendalikan baginya.

\section{KESIMPULAN DAN SARAN}

\subsection{Kesimpulan}

Penerapan ipteks ini telah dilaksanakan untuk meningkatkan pemahaman Ibu-Ibu PKK terhadap anggaran serta penerapannya pada rumah tangga mereka yang diharapkan dengan pengetahuan tentang anggaran akan membantu Ibu-Ibu PKK dalam mengelola keuangan rumah tangga. Analisis yang baik akan meningkatkan keberhasilan dari pelaksanaan penyusunan anggaran kas tersebut.

\subsection{Saran}

Diharapkan adanya keberlanjutan kegiatan yang serupa dengan materi lanjutan di kelompok masyarakat yang sama, agar terbentuknya kelompok binaan masyarakat yang mampu menerapkan ilmu pengetahuan dalam menyelesaikan masalah yang dihadapi sehari hari, khususnya dalam bidang administrasi dan manajerial yang bertujuan untuk mengembangkan kemampuan kelompok masyarakat tersebut.

\section{DAFTAR PUSTAKA}

Atika, L., \& Pusung, R. (2018). Ipteks pengelolaan kas kecil (petty cash) pada PT. PLN (PERSERO) Unit Induk Pembangunan Sulawesi Bagian Utara. Jurnal Ipteks Akuntansi Bagi Masyarakat, 2(2). https://doi.org/10.32400/jiam.2.02.2018.21778

Horngren, C. T., Harrison Jr., W. T., \& Oliver, M. S. (2012). Accounting, $9^{\text {th }}$ Edition. New Jersey : Pearson Education, Inc.

Kakasih, G., Kodong, T., \& Mawikere, L. (2018). Ipteks laporan arus kas sebagai pengukur penilaian kinerja keuangan pada PT. Bank Sulutgo. Jurnal Ipteks Akuntansi Bagi Masyarakat, 2(2). https://doi.org/10.32400/jiam.2.02.2018.21681.

Kieso, D. E., Weygandt, J. J., \& Warfield, T. D. (2013). Intermediate Accounting, $15^{\text {th }}$ Edition. New York : John Wiley \& Sons Inc. 
Laotongan, R., Saerang, D., \& Wokas, H. (2015). Analisis pelaksanaan sistem dan prosedur akuntansi pengeluaran kas pada Dinas Kesehatan Kota Manado. ACCOUNTABILITY, 4(1), 95-104. https://doi.org/10.32400/ja.8416.4.1.2015.95-104.

Lasupu, E., \& Wangkar, A. (2018). Ipteks sistem dan prosedur pengeluaran kas pada UPTD Balai Pendidikan Dan Pelatihan Koperasi Dan Ukm Daerah Provinsi Sulawesi Utara. Jurnal Ipteks Akuntansi Bagi Masyarakat, 2(2). https://doi.org/10.32400/jiam.2.02.2018.21802

Libby, R., Libby, P. A., \& Short, D. G. (2011). Financial Accounting, $7^{\text {th }}$ Edition. New York : McGraw-Hill Irwin.

Tambunan, E., \& Runtu, T. (2018). Ipteks sistem pengendalian internal kas pada PT. Bursa Efek Indonesia KP Papua. Jurnal Ipteks Akuntansi Bagi Masyarakat, 2(2). https://doi.org/10.32400/jiam.2.02.2018.21679.

Taogan, G., Runtuwene, A., Abuno, M., \& Elim, I. (2018). Ipteks pengendalian intern kas pada PT. PLN (PERSERO) Unit Induk Pembangunan Sulawesi Bagian Utara. Jurnal $\begin{array}{llll}\text { Ipteks Akuntansi Bagi } & \text { Masyarakat, }\end{array}$ https://doi.org/10.32400/jiam.2.02.2018.21731.

Tiow, P., \& Tirayoh, V. (2018). Iptek sistem informasi akuntansi pada penerimaan kas di PT. Siaran Radio Modulasi Nada Titian Inspirasi Jaya Manado. Jurnal Ipteks Akuntansi Bagi Masyarakat, 2(2). https://doi.org/10.32400/jiam.2.02.2018.21860.

Usman, Y., \& Rondonuwu, S. (2018). Ipteks penerapan akuntansi kas kecil pada PT. PLN (PERSERO) Rayon Manado Selatan. Jurnal Ipteks Akuntansi Bagi Masyarakat, 2(2). https://doi.org/10.32400/jiam.2.02.2018.21630.

Warren, C. S., Reeve, J. M., \& Duchac, J. E.. (2009). Accounting, $23^{\text {rd }}$ Edition. Mason : South Western Cengage Learning. 